\title{
Pengalaman orang tua anak berkebutuhan khusus mengenai pembelajaran daring selama pandemi COVID-19
}

\author{
Diana Permata Sari ${ }^{1}$, Stephani Paska ${ }^{2}$ \\ ${ }^{12}$ Fakultas Psikologi Universitas Sanata Dharma, Yogyakarta, 55281, Indonesia \\ *Corresponding Author. E-mail: diana_permatas@usd.ac.id, Telp: +6281210918818
}

\begin{abstract}
Abstrak: Tujuan penelitian kualitatif ini adalah menggali perspektif para orang tua terhadap metode pembelajaran daring (dalam jaringan/online) untuk Anak berkebutuhan khusus (ABK) selama masa pandemi COVID-19. Pengambilan data dilakukan dengan metode survei pertanyaan terbuka pada google form kemudian dilanjutkan dengan wawancara melalui aplikasi Whatsapp. Subyek adalah 43 orang tua dari ABK yang berada Jakarta, Jawa Barat, Jawa Tengah, Yogyakarta serta Jawa Timur. Berdasarkan hasil analisis tematik induktif data ditemukan bahwa orang tua sebagai pendamping anak yang utama selama pembelajaran daring merasa bahwa pembelajaran daring tidak hanya memberikan pengalaman secara negatif, namun juga memberikan pengalaman positif bagi para orang tua dan juga anak mereka. Namun, terdapat beberapa orang tua menyimpulkan bahwa pembelajaran daring tidak cocok untuk anak yang memiliki disabilitas tertentu.
\end{abstract}

Kata Kunci: orang tua, ABK, pembelajaran daring, Covid-19

\section{Parent's experience of online learning method for special needs children during COVID-19 pandemic}

\begin{abstract}
This qualitative study aims to investigate parents' experience about online learning method for special needs children during COVID-19. Open-ended survey using google form was done before interviewing subjects with Whatsapp application. There were 43 parents of special needs children from Jakarta, West Java, Middle Java, Yogyakarta and East Java who filled the form. Based on inductive thematic analysis, parent as primary companion during online learning to their children found that they children and themselves had positive and negative experience of online learning method. On the other hand, some parents concluded that online learning was not suitable for some disabilities.
\end{abstract}

Keywords: parent, special needs children, online learning, Covid-19

\section{PENDAHULUAN}

COVID-19 menjadi tantangan terbesar untuk seluruh negara di dunia termasuk Indonesia di tahun 2020. World Health Organization (WHO) per 1 Januari 2021 mengumumkan bahwa kasus corona di Indonesia sudah menembus 743.198 kasus. Virus yang menyerang pernapasan manusia ini, telah menelan korban jiwa hampir 2 juta jiwa di seluruh dunia (WHO, 2020). Awal mula penemuan virus ini berasal dari kota Wuhan di Cina pada akhir tahun 2019. Lalu tersebar ke seluruh dunia di mulai dari benua Asia dan Eropa pada akhir Maret 2020. Kemunculan COVID-19 awalnya tidak bisa dihitung secara sistematik dikarenakan penanganan yang berbeda pada setiap negara (Di Genarro, dkk. 2020). COVID-19 memiliki gejala yang cukup umum seperti demam dan batuk sehingga susah untuk dideteksi hanya dengan kasat mata. Maka, semua orang sangat perlu untuk memperhatikan gejala lain yang menyertai supaya penanganan lebih jauh dapat dilakukan (Susilo, dkk. 2020). Penularan virusnya berlangsung selama 2-14 hari. Resiko akan menjadi tinggi bila orang tersebut berada dalam jarak 1 meter dengan orang terduga terjangkit virus corona, melakukan kontak fisik, ataupun tidak melakukan protokol kesahatan (Handayani, dkk. 2020).

Pesatnya perluasan wabah COVID-19 mengakibatkan dampak buruk di berbagai sektor termasuk bidang pendidikan utamanya sekolah formal. Pendidikan yang ditempuh melalui sekolah formal, bertujuan untuk mengembangkan aspek kepribadian, keterampilan, kognitif serta kemampuan sosial anak (Chomadi \& Salamah, 2018). Namun, kedatangan COVID-19 telah menghentikan pembelajaran yang seharusnya dilakukan di sekolah formal. Pembelajaran di sekolah pun harus hilang dan diganti dengan proses pembelajaran secara daring (dalam jaringan/online) untuk menghindari terjadinya penyebaran di kalangan siswa Indonesia (Menteri Pendidikan, Nomor 4 tahun 2020). 


\title{
J PK (J urnal Pendidikan Khusus), 17 (1), 2021 - 12
}

\author{
Dian Sartika Sari
}

Akhirnya, seluruh belahan dunia menetapkan pembelajaran daring sebagai jalan keluar yang harus dilakukan supaya proses pembelajaran tetap berjalan. Guna mendukung pembelajaran yang tidak ketinggalan jaman, para ahli terus berinovasi dalam menciptakan pembelajaran yang memberdayakan teknologi.

Kemajuan teknologi dimanfaatkan untuk menyokong kegiatan pembelajaran yang tidak memungkinkan dilakukan secara tatap muka (Finkelstein, 2006). Pembelajaran daring dibagi menjadi dua yaitu, asinkronus dan sinkronus. Bila dilihat dari keuntungan untuk siswa, asinkronus merupakan pilihan yang tepat untuk mengasah kemandirian siswa dengan pemberian keleluasaan siswa untuk mengatur jadwal mereka sendiri dalam mengerjakan tugas yang diberikan guru. Namun di balik keuntungan tersebut, interaksi antara siswa dan guru terbatas dikarenakan metode tidak terbatas oleh ruang dan waktu. Siswa dipercaya dapat berusaha melakukan semuanya sendiri dengan penugasan yang diberikan. Berlawanan dengan asinkronus, sinkronus bertumpu pada pembelajaran real time. Tujuan metode ini mengedepankan pengalaman murid dengan keterlibatan siswa di dalam pembelajaran walaupun dilakukans secara daring (Sistek-Chandler, 2019). Umumnya, pembelajaran ini menggunakan telepon, bertukar pesan lewat gawai atau video call agar pengajar bisa secara virtual menyampaikan materi (Negash, dkk., 2008).

Menghilangnya sesi tatap muka pada sekolah formal, tentu saja menjadi kekhawatiran tersendiri bagi siswa, orang tua maupun pihak sekolah di Indonesia karena harus beradaptasi pada situasi pembelajaran yang baru. Orang tua dan siswa harus mengubah pola keseharian mereka di rumah agar pembelajaran dapat terus berlangsung (Aji, 2020). Rutinitas yang baru menjadi kendala bagi orang tua yang tidak memungkinkan untuk meninggalkan pekerjaan mereka. Orang tua yang bekerja di pabrik ataupun ladang harus tetap bekerja demi keberlangsungan hidup keluarganya. Oleh karena itu, banyak siswa yang tidak mendapat pendampingan dari orang tua saat proses pembelajaran (Lutfiah, 2020). Tidak sedikit orang tua menyuarakan kerugian yang dialami anak mereka karena tidak mengalami pembelajaran secara langsung. Walaupun begitu, banyak orang tua mengakui wawasan anak mereka bertambah seiring berjalannya pembelajaran daring (Kusumah \& Cahyati, 2020).

Pengalaman siswa terkait pembelajaran daring tak luput disorot. Siswa di Indonesia merasakan keuntungan pembelajaran daring dari segi kelonggaran waktu maupun tempat. Namun, banyak siswa yang menyatakan bahwa kehadiran pembelajaran daring merupakah hal yang berat untuk mereka jalani, sebab sudah terbiasa dengan tatap muka (Hidayat \& Noeraida, 2020). Orang tua dan siswa juga mengutarakan tentang keterbatasan kuota untuk mengikuti pembelajaran, ditambah dengan jaringan yang terkadang jelek untuk mengakses aplikasi pembelajaran. Selain itu, motivasi belajar pun ikut menurun dikarenakan siswa merasa jenuh akibat terlalu lama di rumah (Mastura \& Santaria, 2020). Lebih lanjut, beberapa siswa menyatakan bahwa diri mereka lebih mandiri dan lebih percaya diri. Mereka merasa tertantang sehingga menimbulkan adanya rasa tanggung jawab untuk mempersiapkan pelajaran. Kepercayaan diri para siswa juga terbangun yang diperlihatkan dengan keberanian dalam berpendapat. Hal ini dikarenakan para siswa tidak harus bertatap muka dengan pengajar ketika harus berbicara (Sadikin \& Hamidah, 2020) Tak hanya dirasakan sekolah umum, perubahan ini juga berdampak pada sekolah luar biasa.

Kurang baiknya sistem edukasi menjadi alasan utama susahnya menerapkan pembelajaran daring di sekolah luar biasa. Hasil wawancara awal dengan guru di SLB menyebutkan bahwa baru kali ini pembelajaran daring dilakukan dan mereka menemukan kesulitan di awal terkait pengoperasian beberapa media pembelajaran karena selama ini mereka tidak dipersiapkan untuk mengajar secara daring. Kemudian, terdapat faktor lain yang mempengaruhi yaitu, kurangnya dukungan dari guru dan tenaga profesional seperti psikolog dianggap belum memadai untuk mengimbangi berjalannya pembelajaran daring bagi siswa berkebutuhan khusus (Duraku \& Nagavci, 2020). Hal ini didukung dengan bukti yang ada di lapangan. $\mathrm{M}$ adalah salah satu orang tua yang memiliki anak berkebutuhan khusus. Ia memiliki pengalaman bahwa guru dari anaknya tidak responsif dalam memberikan materimateri pelajaran selama pembelajaran daring sehingga orang tau harus berpikir secara mandiri terkait pembelajaran.

Jamila (2005) menambahkan bahwa siswa berkebutuhan khusus itu berbeda secara mental,

kemampuan sensori, kemampuan komunikasi, karakteristik fisik serta kemampuan sosial. Keluhan yang sama diajukan oleh siswa-siswa yang sudah terbiasa dengan adanya pendamping khusus saat melakukan pembelajaran tatap muka. Kemunculan pembelajaran daring ini menyulitkan pelajar karena 
tidak ada yang mendampingi untuk menjelaskan lebih lanjut tentang materi yang didapat serta untuk membantu mengajukan pertanyaan pada pengajar (Ro’fah, Hanjarwati, \& Suprihatiningrum, 2020).

Berdasarkan pada penelusuran literatur, penelitian yang selama ini ada, masih didominasi dengan pengalaman orang tua dari anak yang bukan berkebutuhan khusus selama mendampingi anak mereka selama pandemi. Maka dari itu, peneliti mendeskripsikan tentang pengalaman orang tua anak berkebutuhan khusus dalam mendampingi anak pada metode pembelajaran daring selama pandemi Covid-19. Penelitian ini ingin mengetahui secara mendalam pengalaman positif serta negatif yang dialami oleh orang tua selama menjadi pendamping dalam pembelajaran daring. Selain itu, dengan adanya penelitian ini dapat membantu pihak pemerintah serta institusi sekolah dalam menentukan kebijakan-kebijakan di masa mendatang dalam rangka pembelajaran daring bagi ABK mengingat bahwa mereka memiliki tantangan tersendiri dibandingkan anak bukan berkebutuhan khusus.

\section{METODE}

Penelitian ini merupakan penelitian kualitatif dengan menggunakan survei secara daring melalui google form yang disebar di media sosial pada bulan Juni hingga Juli 2020. Survei berisi pertanyaan-pertanyaan terbuka mengenai data demografis, jenis media yang digunakan dalam pembelajaran daring, model pembelajaran yang dilakukan selama ini serta pengalaman negatif dan positif yang mereka temui selama pembelajaran daring. Subjek dipilih dengan menggunakan teknis purposive sampling atau teknik sample bertujuan dengan kriteria subjek antara lain orang tua dari anak berkebutuhan khusus yang berlokasi di Jakarta, Jawa Barat, Jawa Tengah, Yogyakarta serta Jawa Timur. Peneliti menyebarkan survei ke beberapa Sekolah Luar Biasa, sekolah inklusi serta sekolah regular yang menerima siswa berkebutuhan khusus berdasarkan informasi yang didapat melalui media sosial Instagram maupun beberapa kenalan peneliti yang memiliki jaringan dengan orang tua dari anak berkebutuhan khusus.

Teknik pengumpulan data dilakukan dengan metode wawancara dan juga member-checking. Setelah para subjek mengisi survei, peneliti dan para asisten menghubungi mereka secara personal dalam rangka memperdalam jawaban-jawaban yang telah mereka berikan dalam survei. Peneliti dan tim melakukan wawancara lebih lanjut kepada para partisipan serta dilakukan member-checking dalam rangka menjaga validitas dan reliabilitas penelitian.Wawancara dilakukan secara tidak langsung melalui telepon dan aplikasi Whatsapp.

Metode analisis data yang akan digunakan dalam penelitian ini adalah metode analisis tematik cara induktif. Tujuan analisis tematik adalah untuk menemukan dan menganalisis pola atau tema yang muncul dalam data (Braun \& Clarke, 2006). Kemudian, analisis induktif adalah suatu proses coding data tanpa berusaha menyesuaikannya dengan kerangka coding yang sudah ada sebelumnya, ataupun pandangan pribadi yang peneliti miliki (Braun \& Clarke, 2006). Jadi, tema diidentifikasikan berdasarkan data yang telah diperoleh itu sendiri.

\section{HASIL DAN PEMBAHASAN}

A. Data demografis subjek penelitian

Berdasarkan Tabel 1, total subjek yang berpartisipasi mengisi google form yang disebar oleh peneliti berjumlah 43 orang dengan komposisi 37 orang adalah ibu dan 6 subjek adalah bapak dari siswa berkebutuhan khusus. 
J PK (J urnal Pendidikan Khusus), 17 (1), 2021 - 14

Dian Sartika Sari

Tabel 1. Data Demografis Subjek

\begin{tabular}{|c|c|c|}
\hline Karakteristik demografis & Frekuensi & Persentase \\
\hline \multicolumn{3}{|l|}{ Jenis kelamin } \\
\hline Perempuan & 37 & $86 \%$ \\
\hline Laki-laki & 6 & $14 \%$ \\
\hline \multicolumn{3}{|l|}{ Usia } \\
\hline$<25$ tahun & 3 & $4.7 \%$ \\
\hline 25 - 30 tahun & 5 & $11.6 \%$ \\
\hline 31 - 40 tahun & 19 & $44.2 \%$ \\
\hline 41 - 50 tahun & 14 & $32.6 \%$ \\
\hline$>50$ tahun & 2 & $4.7 \%$ \\
\hline \multicolumn{3}{|l|}{ Latar belakang pendidikan } \\
\hline SD & 4 & $9.3 \%$ \\
\hline SMP & 16 & $37.2 \%$ \\
\hline SMA/SMK/Sederajat & 13 & $30.2 \%$ \\
\hline D3 & 1 & $2.3 \%$ \\
\hline S1 & 9 & $20.9 \%$ \\
\hline \multicolumn{3}{|l|}{ Daerah asal } \\
\hline Jawa Tengah & 7 & $16.3 \%$ \\
\hline DIY & 32 & $73.4 \%$ \\
\hline Jawa Timur & 3 & $7 \%$ \\
\hline Lainnya & 1 & $2.3 \%$ \\
\hline \multicolumn{3}{|l|}{ Jenjang pendidikan anak } \\
\hline Prasekolah/TK & 11 & $25.6 \%$ \\
\hline SD & 22 & $51.2 \%$ \\
\hline SMP & 9 & $20.9 \%$ \\
\hline SMA & 1 & $2.3 \%$ \\
\hline \multicolumn{3}{|l|}{ Jenis Institusi Pendidikan } \\
\hline SLB A & 2 & $4.7 \%$ \\
\hline SLB B & 12 & $27.9 \%$ \\
\hline SLB C & 10 & $23.3 \%$ \\
\hline SLB D & 4 & $9.3 \%$ \\
\hline SLB UMUM & 12 & $27.9 \%$ \\
\hline Sekolah Reguler & 2 & $4.7 \%$ \\
\hline Sekolah Inklusi & 1 & $2.3 \%$ \\
\hline
\end{tabular}

Data demografis di atas menunjukkan bahwa mayoritas subjek berusia antara 31-40 tahun dan berasal dari daerah Yogyakarta. Mayoritas subjek memiliki latar belakang pendidikan Sekolah Menengah Pertama (SMP) yaitu sebanyak 37.2\% dan Sekolah Menengah Atas (SMA) yaitu sebanyak $30.2 \%$. Kemudian kelompok terbesar orang tua yang berpartisipasi pada penelitian ini adalah orang tua yang memiliki anak duduk di bangku Sekolah Dasar. Sebanyak 27.9\% anak bersekolah di SLB Umum dan SLB B. Lalu diikuti oleh mereka yang bersekolah di SLB C, SLB D, SLB A, sekolah reguler serta sekolah inklusi.

Selain data demografis, berdasarkan pada hasil survei diketahui bahwa menurut para orang tua, pihak sekolah belum pernah melakukan pembelajaran secara daring sebelum pandemi $(72.1 \%)$. Selama masa pandemi Covid-19, para guru menggunakan beberapa media. Media yang paling banyak digunakan selama pembelajaran daring adalah Whatsapp (95.3\%) disusul oleh Youtube dan Zoom dengan persentase masing-masing sebanyak $11.6 \%$. 
B. Temuan kategori, tema dan sub-tema

Berdasarkan analisis data kualitatif yang dilakukan oleh peneliti pada Tabel 2. Terdapat dua kategori besar yaitu pengalaman positif dan negatif.

Tabel 2. Temuan Kategori, Tema dan Sub-Tema

\begin{tabular}{|c|c|c|}
\hline Kategori & Tema & Subtema \\
\hline \multirow{4}{*}{$\begin{array}{l}\text { Pengalaman } \\
\text { positif }\end{array}$} & Pendampingan orang tua & $\begin{array}{l}\text { Kesabaran dalam menghadapi anak } \\
\text { Kesempatan mengetahui kemampuan dan kebutuhan } \\
\text { anak } \\
\text { Kesempatan mengajari anak } \\
\text { Manajemen waktu lebih baik }\end{array}$ \\
\hline & Perkembangan positif anak & $\begin{array}{l}\text { Peningkatan hasil belajar siswa sebanyak 10\% } \\
\text { Kemajuan dalam kemampuan anak } \\
\text { Kemandirian mengerjakan tugas sekolah dan rumah }\end{array}$ \\
\hline & Keterampilan orang tua & $\begin{array}{l}\text { Teknologi } \\
\text { Materi pelajaran } \\
\end{array}$ \\
\hline & $\begin{array}{l}\text { Relasi orang tua-anak dan } \\
\text { orang tua- guru }\end{array}$ & $\begin{array}{l}\text { Orang tua mengetahui kemampuan anak } \\
\text { Kedekatan orang tua dan anak } \\
\text { Kedekatan orang tua dan guru }\end{array}$ \\
\hline \multirow{4}{*}{$\begin{array}{l}\text { Pengalaman } \\
\text { negatif }\end{array}$} & $\begin{array}{l}\text { Kesulitan non-finansial } \\
\text { orang tua }\end{array}$ & $\begin{array}{l}\text { Pengaturan waktu yang rumit } \\
\text { Kesulitan mengkondisikan anak di rumah } \\
\text { Kewajiban orang tua untuk bekerja di luar rumah }\end{array}$ \\
\hline & Kendala finansial orang tua & $\begin{array}{l}\text { Kuota internet yang minim } \\
\text { Sinyal HP tidak memadai }\end{array}$ \\
\hline & Kompetensi guru & $\begin{array}{l}\text { Guru kurang memantau } \\
\text { Guru kurang efektif mengajar misal lupa kirim materi }\end{array}$ \\
\hline & Kendala anak & $\begin{array}{l}\text { Minim interaksi dengan teman } \\
\text { Kondisi emosional dan fisik yang kurang } \\
\text { Kebutuhan khusus anak }\end{array}$ \\
\hline
\end{tabular}

Masing-masing pengalaman ini menghasilkan beberapa tema serta sub-tema. Pengalaman positif yang dirasakan oleh orang tua terkait pembelajaran secara daring adalah (1) pendampingan orang tua, (2) perkembangan positif anak, (3) bertambahnya keterampilan orang tua, (4) relasi positif yang terbangun. Sedangkan pengalaman negatif orang tua terkait dengan (1) kesulitan non-finansial, (2) kendala finansial, (3) kompetensi guru, (4) kendala anak.

\section{B.1. Pengalaman Positif}

Dukungan emosional ditunjukkan oleh salah satu subjek yang menyatakan bahwa dia cukup bersabar dalam menghadapi perilaku anak selama belajar. Subjek R5 merasa bahwa ia menjadi lebih sabar dalam menghadapi anaknya yang kadang susah untuk diajak belajar dan diminta menyanyi. Melalui belajar daring, orang tua melihat juga bahwa ada perkembangan positif baik fisik maupun non-fisik anak seperti fisiknya yang menjadi jarang sakit, kemandirian, kreativitas serta tanggung jawab. Hal ini didukung oleh pernyataan subjek R4 yang menyatakan bahwa anaknya mudah tertular temannya di sekolah yang sedang sakit, semenjak pembelajaran daring, anaknya jarang sekali sakit. Selain kemajuan dalam kondisi fisik, menurut subjek R27, anaknya mengalami kemajuan terkait dengan kemandiriannya, misalnya penugasan untuk membantu orang tua selama di rumah. Selain dukungan, orang tua merasa meningkatnya kemampuan orang tua dalam memahami bahan ajar serta 


\section{J PK (J urnal Pendidikan Khusus), 17 (1), 2021 - 16}

Dian Sartika Sari

penggunaan media dan teknologi internet selama mendampingi anak mereka belajar di rumah. Subjek R3 sebagai orang tua misalnya, sudah belajar huruf-huruf braile dan dapat mengajari anaknya. Sebelumnya subjek R3 tidak mengenal huruf-huruf braile. Selain, itu subjek R26 dan R8 menyatakan jika mereka lebih mengetahui materi pelajaran anak dan terbantu dengan adanya Google dan Youtube.

Selama pembelajaran daring, orang tua juga merasa bahwa mereka memiliki relasi yang lebih baik dengan anak mereka karena mengetahui perkembangan anak. Selain itu, relasi mereka dengan para guru terjalin lebih baik dibanding sebelum pandemi. Hal ini didukung oleh pernyataan dari subjek R30 yang mengatakan jika ia menjadi lebih tahu mengenai kemampuan anaknya serta ditambahkan oleh subjek R26 yang menjadi lebih dekat dengan guru karena lebih intens dalam komunikasi mengenai perkembangan anaknya tersebut.

\section{B.2. Pengalaman negatif}

Pengalaman negatif orang tua selama mendampingi anak belajar di rumah antara lain: (1) Kendala situasi orang tua, (2) Kendala finansial orang tua, (3) Kompetensi guru, (4) Kemampuan anak. Hal ini serupa dengan temuan dari subjek R34 dan R4 terkait kendala teknis tersebut. Menurut mereka, selama pembelajaran daring kuota menjadi sering habis dan juga bertambahnya kebutuhan karena mencetak materi pelajaran.

Selain kendala dalam hal finansial, orang tua juga menemui beberapa kesulitan dalam mendampingi anak untuk belajar selama pandemi Covid-19, seperti kesulitan dalam menerangkan materi/ bahan ajar dan juga kesulitan mengatur waktu dengan kesibukan orang tua untuk mengerjakan pekerjaan lainnya. Menurut subjek R27, guru lebih menguasai materi dibandingkan orang tua. Sedangkan subjek R23 merasa kesulitan karena harus membagi waktu antara mendampingi selama belajar daring, mengurus bayi serta bekerja di luar rumah.

Orang tua juga menemukan bahwa ada beberapa guru yang dinilai kurang sesuai dalam memberi penilaian dan kurang dapat memberikan pengajaran yang diharapkan dengan metode daring ini. Subjek R10 merasakan bahwa guru sering memberi nilai tidak sesuai dan juga kurang teliti. Hal itu disebabkan menurut subjek R36 karena guru tidak dapat berinteraksi dengan siswa seperti biasanya sehingga pengajaran menjadi kurang maksimal.

Salah satu keluhan dari para orang tua yang banyak disebutkan adalah terkait kondisi anak yang tidak mood serta tidak fokus saat melakukan pembelajaran daring yang naik turun. Selain itu, menurut orang tua, interaksi anak mereka dengan teman sebayanya yang minim membuat mereka juga kurang bersemangat. Salah satu subjek R23 menjelaskan lebih lanjut bahwa anak menjadi tidak mood karena mereka mengerjakan tugas saat orang tua di rumah dan waktu tersebut sebenarnya merupakan jam tidurnya. Selain itu, menurut subjek R40 anak menjadi jarang bersosialisasi dengan teman-temannya padahal mereka sangat butuh berinteraksi dengan teman sebayanya agar mereka dapat berkembang. Hal lain yang ditemui oleh para orang tua terkait pembelajaran daring adalah mengenai menurunnya kemampuan anak berkebutuhan khusus.

\section{Pembahasan}

Mayoritas guru, menggunakan media Whatsapp selama pembelajaran daring yang dilakukan selama pandemi. Guru memberikan materi kemudian meminta orang tua dan siswa mengirimkan tugasnya. Menurut Finkelstein (2016), pembelajaran tersebut masuk dalam kategori asinkronus. Asinkronus tidak bertumpu pada pembelajaran real time. Melalui pembelajaran ini, siswa dapat mengatur secara mandiri waktu untuk belajar. Berdasarkan pada temuan tematik di atas, didapatkan hasil bahwa pengalaman positif dan negatif dari kegiatan pembelajaran daring ternyata tidak hanya berdampak pada ABK saja, melainkan juga pada orang tua serta guru. Hal ini sesuai dengan hasil penelitian yang dilakukan oleh Purwanto, dkk. (2020) yang juga menyatakan bahwa guru dan orang tua juga terkena dampak dari pembelajaran daring selain siswa itu sendiri. Masih menurut sumber yang sama, orang tua dari non- ABK pun terkena dampak pembelajaran daring terkait bertambahnya ketersediaan waktu untuk pendampingan anak, kuota untuk internet, serta kesulitan melakukan pekerjaan lain saat mendampingi anak untuk belajar. Hal ini didukung dengan penelitian dari Emiyati dan Haning (2020), kendala utama orang tua adalah terkait biaya untuk kuota dan biaya print selama pembelajaran daring.

Orang tua sangat berperan penting selama pembelajaran dengan sistem daring ini (Ahsani, 2020). Dukungan dan pendampingan yang diberikan orang tua selama pandemi ini bentuknya bermacam-macam. Orang tua dari ABK pun melihat bahwa anak mereka juga mengalami dampak 
negatif yang sama seperti penelitian Purwanto, dkk. (2020). Namun, ada satu pengalaman khusus yang ditemui pada ABK selama pembelajaran daring yaitu terkait adanya kebutuhan khusus anak yang menyulitkan mereka untuk belajar melalui pembelajaran daring. Menurut Krishnan, dkk. (2020), siswa tuli dengan bantuan alat dengar mendapatkan beberapa tantangan selama pembelajaran daring seperti alat bantu dengar yang tidak memadai baik dari pengajar maupun dari siswa, kurang dapat memahami materi yang disampaikan serta teknologi yang ada, dan juga efek secara emosional yang terjadi selama pembelajaran daring.

Berdasarkan temuan dari Mauludy (2020), selama pandemi ini kemampuan anak yang memiliki keterbatasan mental mengalami kemunduran selama pembelajaran daring. Temuan ini didukung pula oleh beberapa subjek penelitian yang menyatakan bahwa anak mereka terkadang merasa tidak mood ketika mengerjakan tugas atau belajar di rumah. Ada juga anak yang menjadi sering sakit-sakitan semenjak belajar di rumah sehingga tidak dapat mengikuti pembelajaran secara penuh.

Menurut Krishnan, dkk. (2020) orang tua serta guru berperan sangat penting selama pembelajaran daring. Orang tua berfungsi sebagai fasilitator dalam metode pembelajaran daring dan bukan menggantikan guru dalam mengajar. Kartini (2020) menambahkan bahwa perlu adanya kerjasama antar guru dan orang tua dengan difasilitasi oleh pihak sekolah. Pola komunikasi yang terjalin antara guru dan orang tua disarankan tidak hanya terjalin secara formal tetapi juga informal yaitu melalui chat atau sms. Dengan adanya pola komunikasi dan kerjasama antara pihak sekolah dan orang tua dapat mengatasi masalah-masalah yang muncul dalam pembelajaran daring selama pandemi Covid-19.

\section{SIMPULAN}

Berdasarkan hasil analisis tematik data maka dapat disimpulkan bahwa beberapa tema mengenai pengalaman positif dan negatif para orang tua selama memberikan pengajaran secara daring. Pengalaman positif yang dimiliki oleh orang tua dengan ABK adalah terbangunnya relasi positif antara mereka dengan guru dari anak mereka. Selain itu, orang tua juga melihat bahwa keterampilan mereka pun bertambah terutama terkait penguasaan materi pelajaran anak dan penggunaan teknologi. Keterampilan lain yang dinilai orang tua bertambah adalah keterampilan orang tua dalam mengelola emosi mereka. Orang tua dituntut untuk memiliki kesabaran selama mendampingi anak mereka. Orang tua pun melihat bahwa anak-anak mereka mengalami perkembangan positif secara fisik, kognitif serta sosioemosi (terutama terkait kemandirian) ketika mereka menjalani pembelajaran daring.

Sedangkan pengalaman negatifnya terkait dengan situasi mereka yang memiliki kesibukan bekerja atau mengasuh anak lainnya sehingga mereka merasa kesulitan dalam membagi waktu. Kesulitan lainnya adalah terkait keuangan karena meningkatnya kebutuhan untuk membeli kuota internet serta mencetak materi pelajaran. Ada juga orang tua yang merasa meragukan kompetensi guru dalam memberikan pengajaran selama menggunakan metode daring. Guru menjadi tidak teliti serta tidak maksimal memberikan pengajaran karena mereka tidak berinteraksi secara langsung dengan siswa. Terdapat juga orang tua yang merasa bahwa anak mereka menjadi menurun kemampuannya karena mereka tidak bisa bersosialisasi dengan teman-temannya serta sering menjadi tidak mood ketika sedang belajar. Selain tema-tema yang sudah disajikan, ada sedikit orang tua yang merasa bahwa pembelajaran daring ini tidak diberikan pada anak berkebutuhan khusus karena mereka kesulitan dalam penggunaan media selama pembelajaran daring.

\section{DAFTAR PUSTAKA}

Ahsani, E.L.F. (2020). Strategi orang tua dalam mengajar dan mendidik anak dalam pembelajaran at the home masa pandemi COVID-19. JurnalAL_Athfal, 3(1), 37-46

Aji, S. R. H. (2020). Dampak Covid-19 pada Pendidikan di Indonesia: Sekolah, Keterampilan, dan Proses Pembelajaran. Jurnal Sosial \& Budaya Syar-I, 7(5), 395-402. https://doi.org/10.15408/sjsbs.v7i5.15314

Braun, V., \& Clarke, V. (2006). Using thematic analysis in psychology. Qualitative Research in Psychology, 3(2), 77-101. https://doi.org/10.1191/1478088706qp063oa

Chomadi, H. \& Salamah. (2018) Pendidikan dan Pengajaran: Strategi Pembelajaran Sekolah. Jakarta : PT Grasindo 
Di Genarro, G., Pizzol, D., Marotta, C., Antunes, M., Racalbuto, V., Veronese, N., Smith, L. (2020). Coronavirus Diseases (Covid-19) Current Status and Future Perspectives: A Narrative Review. International Journal of Environmental Research and Public Health 17, (8), 1-11. https://doi.org/10.3390/ijerph17082690

Duraku, Z. H. \& Nagavci, M. (2020). The Impact of the COVID-19 pandemic on the education of children with disabilites.https://doi.org/10.13140/RG.2.2.17807.41125

Emiyati, A., \& Harming. (2020). Kendala orang tua menghadapi anak belajar di rumah dalam menghadapi situasi COVID-19. Civic-culture: Jurnal Ilmu Pendidikan Pkn dan Sosial Budaya, 4(1), 8-16

Finkelstein, J. (2006). Learning in Real Time: Synchronous Teaching and Learning Online. San Fransisco : Jossey-Bass

Handayani, D. et al. (2020). Penyakit Virus Corona 2019. Jurnal Respirasi Indonesia, 40(2), 119-129. https://jurnalrespirologi.org/index.php/jri/article /view/101/110

Hidayat, D. \& Noeraida, N. (2020). Pengalaman Komunikasi Siswa Melakukan Kelas Online Selama Pandemi COVID-19. JIKE: Jurnal Ilmu Komunikasi Efek, 3(2), 172-182.https://ejournal.umc.ac.id/index.php/jike/article/view/1017/757

Jamila, M., K., A. (2005). Special Education for Students with Special Needs. Kuala Lumpur. PTS Publiction \& Distributions Sdn. Ltd.

Krishnan, I.A., De Mello, G., Kok, S.A., Sabapathy, S.K., Munian, S., Ching, H.S.,...Kanan, V.N. (2020). Challenges faces by hearing impairment students during COVID-19. Malaysian Journal of Social Sciences and Humanities, 5(8), 106-116. https://doi.org/1047405/mjssh.v5i8.472

Kusumah, R. \& Cahyati, N. (2020). Peran orang tua Dalam Menerapkan Pembelajaran di Rumah Saat Pandemi Covid 19. Jurnal Golden Age, Universitas Hamzawadi, 4(1), 152-159. Retrieved from https://e-journal.hamzanwadi.ac.id/index.php/jga/article/view/2203

Lutfiah, S. Z. (2020). Persepsi Orang tua Mengenai Pembelajaran Online di Rumah Selama Pandemi COVID-19. 2(2), 69-73. Dealektik, 2(2), 69-73. Retrieved from https://journal.umbjm.ac.id/index.php/idealektik/article/view/554

Mastura, M. \& Santaria, R. (2020). Dampak Pandemi Covid-19 terhadap Proses Pengajaran bagi Guru dan Siswa. Jurnal Studi Guru dan Pembelajaran, 3,(2), 289-295. Retrieved from https://ejournal.my.id/jsgp/article/view/293/293

Mauludy, N., B. (2020). Dampak COVID-19 terhadap penerapan "Belajar Daring” pada siswa luar biasa di SD Bandar Kidul 2 Kota Kediri. Prosiding Seminar Nasional 2020: Surabaya

Mendikbud RI. 2020. Peraturan Menteri Pendidikan dan Kebudayaan RI Nomor 4 tentang Pelaksanaan Kebijakan Pendidikan dalam Masa Darurat Penyebaran Coronavirus Disease (Covid-19). Retrieved from https://www.kemdikbud.go.id/main/blog/2020/03/se-mendikbudpelaksanaan-kebijakan-pendidikan-dalam-masa-darurat-penyebaran-covid19

Negash, S., Whitman, M.E., Woszczynski, A. B., Hoganson, K., Mattord, H. (2008). Handbook of Distance Learning for Real-Time and Asynchronous Information Technology Education. Hershey: IGI Global

Purwanto, A., Pramono, R., Asbari, M., Santoso, P.B., Wijayanti, L.M., Hyun, C.C., Putri. R.S. (2020). Studi Eksploratif Dampak Pandemi COVID-19 Terhadap Proses Pembelajaran Online di Sekolah Dasar. EduPsyCouns Journal :Journal of Educations, Psychology and Counseling, 2(1), 1-12. Retrieved from https://ummaspul.e-journal.id/Edupsycouns/article/view/397

Ro'fah, R. Hanjarwati, A. \& Suprihatiningrum, J. ( 2020). Is Online Learning Accessible During COVID-19 Pandemic? Voices and Experiences of UIN Sunan Kalijaga Students With Disabilities. Nadwa : Jurnal Pendidikan Islam, 14(1), 1-36. Retrieved from https://journal.walisongo.ac.id/index.php/Nadwa/article/view/5672/pdf 
Sadikin, A. \& Hamidah, A. (2020). Pembelajaran daring di tengah wabah COVID-19. BIODIK: Jurnal Ilmiah Pendidikan Biologi, 6(2), 214-224. Retrieved from https://doi.org/10.22437/bio.v6i2.9759

Sistek-Chandler, C. M. (2019). Exploring online learning through synchronous and asynchronous Instructional Methods. Pennsylvania : IGI Global

Susilo, A., Rumende, C.M., Pitoyo, C.W., Santoso, W, D., Yulianti, M.,...Yunihastuti, E. (2020). Coronavirus Disease 2019: Tinjauan literatur terkini. Jurnal Penyakit Dalam Indonesia, 7(1), 45-67. Retrieved from http://jurnalpenyakitdalam.ui.ac.id/index.php/jpdi/article/view/415/228

World Health Organization. 2021. Update on coronavirus disease in indonesia. Retrieved from https://www.who.int/indonesia/news/noverl-coronavirus/

\section{PROFIL SINGKAT}

Penulis pertama bernama Diana Permata Sari, S.Psi., M.Sc adalah seorang dosen di Fakultas Psikologi Universitas Sanata Dharma dengan bidang peminatan Psikologi Perkembangan dan Psikologi Pendidikan. Selain itu juga, penulis pertama adalah salah satu Steering Commitee dari Pusat Studi Individu Berkebutuhan Khusus (PSIBK) di institusi yang sama. Penulis menyelesaikan studi S1 dari Fakultas Psikologi, Universitas Indonesia dan studi S2 dari Fakultas Pendidikan jurusan Studi Anak dan Keluarga, Universitas Leiden yang ada di Belanda. Penulis pernah mempublikasikan artikel penelitian mengenai perbedaan parenting self-efficacy yang dimiliki ibu dengan anak disabilitas dan yang tidak memiliki disabilitas. 